\title{
Evaluation of Mallotus oppositifolius Methanol Leaf Extract on the Glycaemia and Lipid Peroxidation in Alloxan-Induced Diabetic Rats: A Preliminary Study
}

\author{
C. O. Nwaehujor, ${ }^{1,2}$ I. I. Ezeigbo, ${ }^{2,3,4}$ and F. C. Nwinyi ${ }^{2,5}$ \\ ${ }^{1}$ Department of Biochemistry, Faculty of Basic Medical Sciences, University of Calabar, Calabar, Cross River State, Nigeria \\ ${ }^{2}$ Department of Veterinary Physiology and Pharmacology, Faculty of Veterinary Medicine, University of Nigeria, \\ Nsukka, Enugu State, Nigeria \\ ${ }^{3}$ Department of Veterinary Physiology, Biochemistry and Pharmacology, College of Veterinary Medicine, \\ Michael Okpara University of Agriculture, Umudike, Abia State, Nigeria \\ ${ }^{4}$ The Royal Veterinary College, University of London, London, UK \\ ${ }^{5}$ Department of Veterinary Pharmacology and Toxicology, Faculty of Veterinary Medicine, University of Abuja, Abuja, Nigeria
}

Correspondence should be addressed to I. I. Ezeigbo; ihechi.ezeigbo@yahoo.com

Received 12 July 2013; Revised 5 September 2013; Accepted 14 September 2013

Academic Editor: Gary S. Shaw

Copyright (c) 2013 C. O. Nwaehujor et al. This is an open access article distributed under the Creative Commons Attribution License, which permits unrestricted use, distribution, and reproduction in any medium, provided the original work is properly cited.

\begin{abstract}
Objective. Mallotus oppositifolius (Geiseler) Müll. Arg. (Euphorbiaceae) is folklorically used to "treat" diabetic conditions in some parts of Nigeria therefore the study, to investigate the extract of the leaves for activities on hyperglycaemia, lipid peroxidation, and increased cholesterol levels in vivo in alloxan diabetic rats as well as its potential antioxidant activity in vitro. Methods. Albino rats $(240-280 \mathrm{~g})$ were given an injection of $120 \mathrm{mg} / \mathrm{kg}$ body weight, i.p. of alloxan monohydrate. After 8 days, diabetic animals with elevated fasting blood glucose levels $(>9 \mathrm{mmol} / \mathrm{L})$ were considered and selected for the study. Results. Oral treatment with the extract administered every $12 \mathrm{~h}$ by gavage at doses of 100,200 , and $400 \mathrm{mg} / \mathrm{kg}$ of the extract to the test rats, for 14 days, resulted in a significant dose-dependent decrease in blood glucose levels from $12.82 \pm 1.02 \mathrm{mmol} / \mathrm{dL}$ to $4.92 \pm 2.01 \mathrm{mmol} / \mathrm{dL}$ at the highest dose of $400 \mathrm{mg} / \mathrm{kg}$ compared to the control drug and glibenclamide as well as attendant significant decline in diabetic rats employed in the study. Conclusion. The extract also showed in vitro concentration-dependent antioxidant activity following the 1,1-diphenyl2-picryl-hydrazyl (DPPH) and ferric reducing assays. Findings further suggest the presence of active antidiabetic and antioxidant principles in M. oppositifolius leaves.
\end{abstract}

\section{Introduction}

Diabetes mellitus (DM) is a multifactorial syndrome resulting from a variable interaction of hereditary and environmental factors. It is characterized by inapt hyperglycaemia caused by damaged $\beta$-cells of the pancreas or resistance to the action of insulin at the cellular level, or possibly a combination of both factors [1, 2]. DM affects more than 200 million people worldwide and is projected to be one of the world's major killers in the next 25 years [3], Nigeria with about 160 million people has the highest number of people with diabetes (approximately $1,338 \times 10^{3}$ ), thus, the highest diabetes prevalence in the African Region (19.1\%), as well as the highest number of people with impaired glucose tolerance with an estimate of about 3.85 million people.

With on-going researches in diabetes and oral hypoglycaemic agents (OHA), the management of DM is still a global problem. One important area in diabetes management receiving particular attention today is that of herbal hypoglycaemic agents. Several factors such as dyslipidemia or hyperlipidemia which are involved in the microvascular and macrovascular complications as well as hyperglycemia are associated with the diabetes disease which is the major cause of morbidity and death [4]. There are also lipoprotein abnormalities with diabetes mellitus [5]. High blood glucose levels not only increase the production of reactive oxygen species (ROS) but 
TABLE 1: The effect of MP extract on the fasting blood glucose levels of test rats.

\begin{tabular}{|c|c|c|c|c|c|c|c|}
\hline \multirow{3}{*}{ Group } & \multirow{3}{*}{ Treatment } & \multirow{3}{*}{$\begin{array}{l}\text { No. of } \\
\text { animals }\end{array}$} & \multirow{3}{*}{ Weight } & \multirow{2}{*}{\multicolumn{4}{|c|}{$\begin{array}{l}\text { Blood glucose levels in } \mathrm{mmol} / \mathrm{L} \\
\text { Sampling time in hours }\end{array}$}} \\
\hline & & & & & & & \\
\hline & & & & 0 & 1 & 6 & 12 \\
\hline I & $\begin{array}{l}\text { Negative control (dist. water), } \\
\text { that is, Diabetic rats }\end{array}$ & 6 & $220.44 \pm 1.55$ & $\begin{array}{l}15.28 \pm 1.89 \\
(0.231)\end{array}$ & $\begin{array}{l}16.26 \pm 1.46 \\
(0.817)\end{array}$ & $\begin{array}{l}17.18 \pm 1.98 \\
(0.280)\end{array}$ & $\begin{array}{l}17.72 \pm 2.14 \\
\quad(0.121)\end{array}$ \\
\hline II & $\begin{array}{l}\text { Diabetic rats treated with MP } \\
100 \mathrm{mg} / \mathrm{kg}\end{array}$ & 6 & $232.54 \pm 0.83$ & $\begin{array}{l}11.48 \pm 0.69 \\
(0.342)\end{array}$ & $\begin{array}{l}11.06 \pm 0.77 \\
(0.108)\end{array}$ & $\begin{array}{l}10.14 \pm 0.62^{*} \\
\quad(0.021)\end{array}$ & $\begin{array}{l}9.12 \pm 1.61 \\
\quad(0.075)\end{array}$ \\
\hline III & $\begin{array}{l}\text { Diabetic rats treated with MP } \\
200 \mathrm{mg} / \mathrm{kg}\end{array}$ & 6 & $233.92 \pm 1.85$ & $\begin{array}{l}11.22 \pm 0.37 \\
\quad(0.583)\end{array}$ & $\begin{array}{l}9.04 \pm 0.52^{*} \\
\quad(0.005)\end{array}$ & $\begin{array}{c}7.36 \pm 0.35^{*} \\
(0.014)\end{array}$ & $\begin{array}{l}7.02 \pm 1.10 \\
(0.770)\end{array}$ \\
\hline IV & $\begin{array}{l}\text { Diabetic rats treated with MP } \\
400 \mathrm{mg} / \mathrm{kg}\end{array}$ & 6 & $220.46 \pm 1.15$ & $\begin{array}{l}12.82 \pm 1.02 \\
(0.021)\end{array}$ & $\begin{array}{l}9.88 \pm 0.58^{* *} \\
\quad(0.0001)\end{array}$ & $\begin{array}{c}5.06 \pm 0.65^{*} \\
(0.013)\end{array}$ & $\begin{array}{l}4.92 \pm 2.01^{*} \\
\quad(0.04)\end{array}$ \\
\hline $\mathrm{V}$ & $\begin{array}{l}\text { Positive control-diabetic rats } \\
\text { treated with glibenclamide } \\
(2 \mathrm{mg} / \mathrm{kg})\end{array}$ & 6 & $221.42 \pm 2.68$ & $\begin{array}{l}11.38 \pm 1.13 \\
\quad(0.108)\end{array}$ & $\begin{array}{l}7.14 \pm 0.22^{*} \\
\quad(0.034)\end{array}$ & $\begin{array}{l}4.72 \pm 0.63 \\
\quad(0.280)\end{array}$ & $\begin{array}{l}4.01 \pm 1.03^{*} \\
\quad(0.033)\end{array}$ \\
\hline
\end{tabular}

Data are expressed as mean \pm SEM. ${ }^{*} P$ values ()$<0.05{ }^{* *} P$ values $\leq 0.001$ compared to the control groups were considered significant.

also affect antioxidant activities of ROS scavenging enzymes $[6,7]$.

Mallotus oppositifolius (Geiseler) Müll. Arg. (Euphorbiaceae), locally known as "Ukpo", is an edible plant to the SouthEastern part of Nigeria. The seed is a special soup thickener in the region. The leaves have ingredients of common antidysentery, antimalarial, and anti-inflammatory remedies [8]. Preliminary phytochemical screening of M. oppositifolius (MP) revealed the presence of secondary metabolites such as alkaloids, phenols, flavonoids, anthraquinones, and cardenolides $[8,9]$. Iwu [10] reported five hydrolysable tannins and cytotoxic phloroglucinol from the bark of another species Mallotus japonicus. MP is also claimed to have antidiabetic activity by local healers in the South-East area of Nigeria. The present study was carried out to evaluate the antihyperglycemic, antioxidant, cholesterol lowering, and lipid peroxidation properties of MP in the rat model.

\section{Materials and Methods}

2.1. Plant Collection and Identification. Fresh M. oppositifolius leaves (MP) were obtained in May 2010 from the demonstration Botanical garden of the University of Nigeria, Nsukka, and authenticated by Mr. A. Ozioko, a Taxonomist with the Biodiversity Development Centre Program (BDCP), Nsukka. Voucher samples were deposited in the herbarium of the Department of Veterinary Physiology and Pharmacology, University of Nigeria, Nsukka, where the research was carried out for reference (UN/VPP-08216). The leaves were air dried on the bench, pulverized into coarse powder, and kept in polythene bags at room temperature $\left(23-25^{\circ} \mathrm{C}\right)$, ready for extraction.

2.2. Plant Extraction. The dried pulverized leaves ( $1500 \mathrm{~g}$ ) were extracted with $80 \%$ methanol in water for $48 \mathrm{~h}$ with intermittent shaking every $2 \mathrm{~h}$. The mixtures were filtered with Whatman number 1 filter paper. The filtrates were concentrated using a rotary evaporator at $38-40^{\circ} \mathrm{C}$. The water was removed using a vacuum lyophilizer, yielding $35.1 \mathrm{~g}$ of brownish-green powder. The powder was resuspended in distilled water before use.

2.3. Animals. Male albino Wistar rats (240-280 g) procured from the Animal Farm of the Faculty of Veterinary Medicine, University of Nigeria, Nsukka, were used for the study. They were kept under the following conditions temperature (25$30^{\circ} \mathrm{C}$ ), relative humidity (40-60\%) and $12 \mathrm{~h}$ lighting cycle, and were fed ad libitum with standardized rat cubes (Argo). The rats were fasted overnight before experimentation but were allowed free access to water. Ethical guidelines in animal handling and use were strictly adhered to in the execution of the study.

Diabetes was induced by a single intraperitoneal injection of $120 \mathrm{mg} / \mathrm{kg}$ body weight of alloxan monohydrate (Sigma, St. Louis, MO, USA) freshly dissolved in distilled water [11]. After 8 days, animals with fasting blood glucose level above $9 \mathrm{mmol} / \mathrm{L}$ were considered diabetic and used for the study.

Thirty mature male albino rats were randomly divided into 5 groups (Table 1). Treatment with the extract was administered every $12 \mathrm{~h}$ by gavage at doses of 100,200 , and $400 \mathrm{mg} / \mathrm{kg}$ of the extract to the test rats for a total of 14 days. The control drug, glibenclamide $(2 \mathrm{mg} / \mathrm{kg})$ was administered the same way for the same duration to rats in the control group.

After 14 days, being the end of the treatment period, the fasting blood glucose level of each rat was measured at $0,1,6$, and $12 \mathrm{~h}$ by a snip-cut at the tip of the tail under mild anaesthesia with the aid of a glucometer (AccuChek Advantage II) as previously described [2, 12, 13]. The rats were then anaesthetized by halothane inhalation. Blood was collected from heart using disposable hypodermic syringes and transferred into EDTA tubes immediately. The blood was then centrifuged at $4000 \mathrm{~g}$ for $10 \mathrm{~min}$ to remove blood cells and recover plasma. Each rat's liver was surgically removed and washed immediately with cold-saline and stored in a freezer set at $-4^{\circ} \mathrm{C}$.

2.4. Biochemical Assays. Two (2) gram weight of liver tissues were homogenised with 20 milliliters of phosphate buffered 
saline (PBS), using Sonic Dismembrator (Fisher Scientific, Indiana, PA, USA). The homogenised liver tissues were used to measure lipid peroxidation using malondialdehyde (MDA) levels as markers [14]. Total cholesterol concentrations were evaluated by the methods described by Allain et al. [15] using assay kits purchased from Quimica Clinica Aplicada, S.A., Spain.

2.5. In Vitro Free Radical Scavenging Assay. The total antioxidant activity of the Mallotus oppositifolius (MP) extract was estimated by the ferric reducing antioxidant power (FRAP) assay [16] and the 1,1-diphenyl-2-picryl-hydrazyl (DPPH) photometric assay [17]. The procedures were carried out in triplicates and the mean used in computations.

2.6. Statistical Analysis. All data were analysed using SPSS version 15 (SPSS Inc., Chicago, IL) and descriptive data were expressed as mean \pm SEM. Differences between the groups were separated by post hoc LSD. Using one-way ANOVA, values were considered significant at $P \leq 0.05$.

\section{Results}

3.1. Plant Extraction. The powder of the $80 \%$ methanol in water extract of Mallotus oppositifolius was brownish-green in colour. The yield of the extract was $2.34 \% \mathrm{w} / \mathrm{w}$.

3.2. Blood Glucose Levels. The extract decreased the blood glucose levels of experimental rats significantly $(P \leq 0.05)$, in a dose-dependent manner (Table 1). Experimental studies reveal that orally administered extracts of MP at a dose of $200 \mathrm{mg} / \mathrm{kg}$ produced significant fasting blood glucose lowering activity in $12 \mathrm{~h}$ compared to the control. An increase in the dose of the extract $(400 \mathrm{mg} / \mathrm{kg})$ showed an even more observable antihyperglycaemic activity in alloxanized rats. This activity at $400 \mathrm{mg} / \mathrm{kg}$ dose was very comparable to that of the reference standard, glibenclamide over the $12 \mathrm{~h}$ period. The variations observed in the blood glucose levels of test rats at the $0 \mathrm{~h}$ may be attributable to idiosyncrasies usually observed with the use of live animals in biological experiments.

3.3. Lipid Peroxidation Test. The study indicated a concentration dependent increase in hepatic lipid peroxidation marker-malondialdehyde (MDA) levels. Table 2 shows the effect of the extract on the liver MDA levels of diabetic rats. The $200 \mathrm{mg} / \mathrm{kg}$ dose had values statistically significant and comparable to the control drug, glibenclamide. Rats administered the highest dose of $400 \mathrm{mg} / \mathrm{kg}$ of the extract had higher MDA levels when compared with the control, although the increase was not significant $(P>0.05)$ (Table 2$)$.

3.4. Total Cholesterol Levels. The total cholesterol levels of experimental animals treated with the methanol extract of MP leaves is presented in Figure 1. The results show that the levels decreased in a dose-dependent manner. The variations
TABLE 2: Malondialdehyde (MDA) levels in the liver of diabetic rats treated with different doses of MP extract.

\begin{tabular}{lccc}
\hline Groups & Treatments & No. of animals & $\begin{array}{c}\text { MDA levels (g/g } \\
\text { tissue) mean } \pm \text { SEM }\end{array}$ \\
\hline I & Dist. Water & 6 & $0.866 \pm 0.02(0.159)$ \\
II & MP $100 \mathrm{mg} / \mathrm{kg}$ & 6 & $0.154 \pm 0.01^{*}(0.031)$ \\
III & MP $200 \mathrm{mg} / \mathrm{kg}$ & 6 & $0.173 \pm 0.03^{* *}(0.001)$ \\
IV & MP $400 \mathrm{mg} / \mathrm{kg}$ & 6 & $1.401 \pm 0.04(0.121)$ \\
V & Glib. $(2 \mathrm{mg} / \mathrm{kg})$ & 6 & $0.187 \pm 0.10^{*}(0.017)$ \\
\hline
\end{tabular}

Data are expressed as mean \pm SEM. ${ }^{*} P$ values ()$<0.05,{ }^{* *} P$ values $<0.001$ compared to the control groups were considered significant.

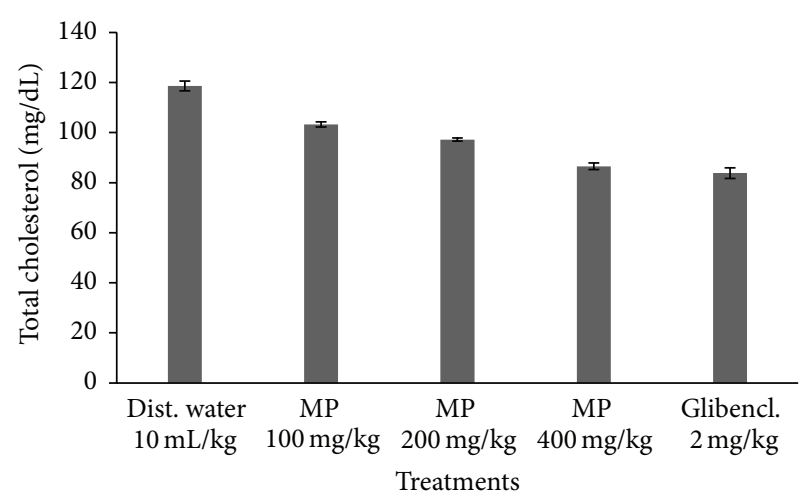

FIGURE 1: Total cholesterol levels in diabetic rats treated with various doses of MP extracts.

in the cholesterol values of the rats compared with the control groups were not significant $(P>0.05)$.

3.5. Free Radical Scavenging Activities. MP demonstrated appreciable antioxidant activity with DPPH radical scavenging method. At the lowest concentration $(10 \mu \mathrm{g} / \mathrm{mL})$, the extract exhibited a mean antioxidant activity of $38 \%$ while ascorbic acid produced $72.6 \%$ (Figure 2). In the same manner, the extract elicited $56.1 \%$ antioxidant activity in contrast to $75.5 \%$ with ascorbic acid at $1000 \mu \mathrm{g} / \mathrm{mL}$. However, at the highest concentration $(400 \mu \mathrm{g} / \mathrm{mL})$, the extract had $78.7 \%$ antioxidant activity compared to $80.0 \%$ with ascorbic acid at the same concentration.

The ferric reducing ability of plasma, a measure of the antioxidant ability, showed that MP produced a dose dependent antioxidant effect. At $10 \mu \mathrm{g} / \mathrm{mL}$, the mean antioxidant power (FRAP) value was $0.3 \mu \mathrm{M}$. The value however increased significantly between $100 \mu \mathrm{g} / \mathrm{mL}$ and $400 \mu \mathrm{g} / \mathrm{mL}$ from $1.1 \mu \mathrm{M}$ to $1.6 \mu \mathrm{M}$, respectively (Figure 3 ). The frap value of the extract at the highest concentration employed in this study was still below the standard which is $1000 \mu \mathrm{g} / \mathrm{mL}$ ascorbic acid $(2.0 \mu \mathrm{M})$. All free radical scavenging assays were carried out in triplicates and the results shown in the figures represent a mean of the values obtained.

\section{Discussion}

The diabetes disease is snowballing very fast and huge amounts of resources are spent in almost all countries to combat this multifactorial metabolic disease. 


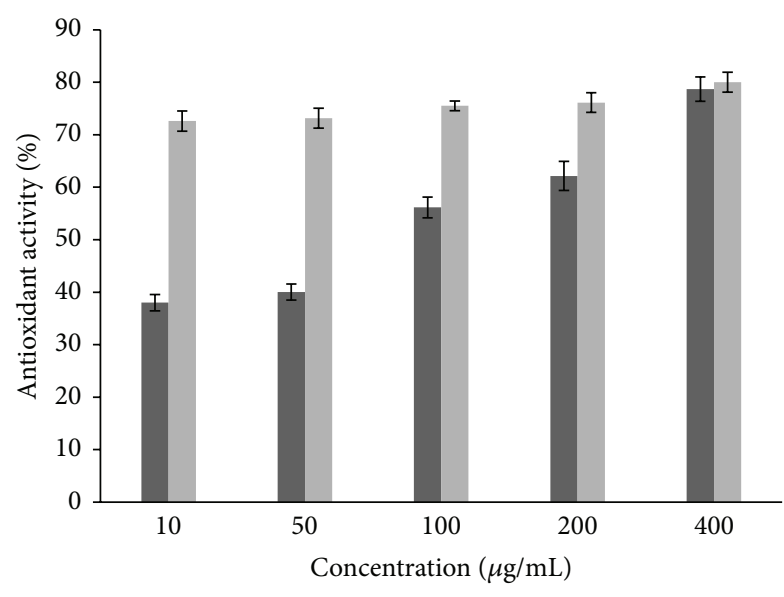

MP

Ascorbic acid

Figure 2: Percent antioxidant activity of MP using DPPH.

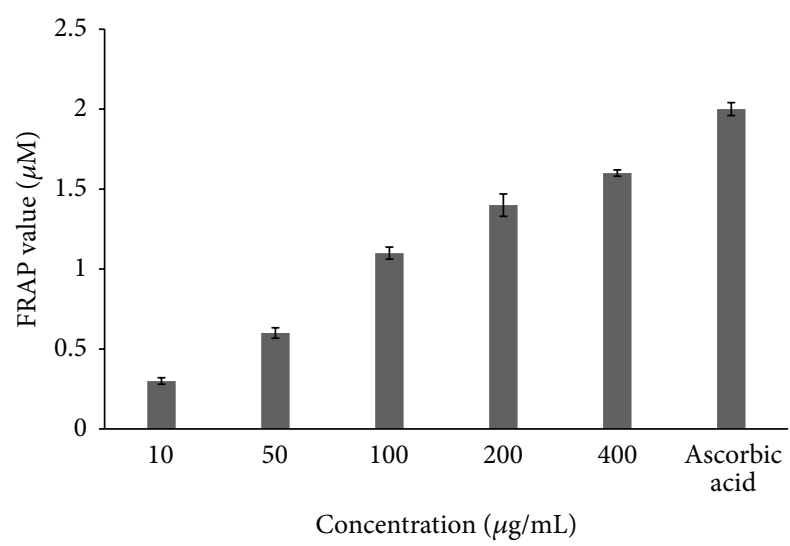

FIGURE 3: In vitro antioxidant activity of $M$. oppositifolius extract using the FRAP assay.

Alloxan, from the literature, has been shown to cause hyperglycaemia in laboratory animals due to increased oxidative stress by elaborated free radicals [12], thus a model for type 1 diabetes studies. Medicinal plants are effective in controlling plasma glucose levels with minimal side effects and are commonly used in under-developing and developing countries like Nigeria as alternative therapy. It has also gained popularity for decades in the treatment of diabetes mellitus [3, 18]; however, majority of the remedies have not been precisely evaluated. Therefore we selected and evaluated the methanol leaf extract of MP for its claimed antidiabetic potentials considering also, its effect on total cholesterol and biomarkers of oxidative stress in vivo and in vitro, respectively.

The results showed that MP significantly reduced the blood glucose and was found to possess significant antioxidant potentials in vitro both in the DPPH and the ferric reducing assay. Diabetes which is associated with impaired glucose metabolism leads to oxidative stress which with an attendant protein glycation will produce free radicals [19]. The lipid peroxidation was evaluated by measuring the raised hepatic MDA levels which lower doses (100 and
$200 \mathrm{mg} / \mathrm{kg}$ ) showed some significant reduction in. Further chronic toxicological evaluations on hepatocytes and other cell lines of organs in the mammalian body may be a step in the right direction.

Earlier phytochemical studies on the MP indicates the presence of large amounts of bitter tasting secondary metabolites known as alkaloids, as well as some phenolics, flavonoids and quinines in the leaves than in the roots $[9,10]$. Reviews on bioactive components in plants express that desirable biological and therapeutic activities observed with plants predominantly range between the alkaloid and flavonoid components [20,21].

Reactive oxygen species (ROS) have been implicated in many pathologies such as heart diseases, cancers, arteriosclerosis, diabetes mellitus, and arthritis [22]. Phenol compounds such as flavonoids isolated from plants scavenge for hydroxyl radicals, superoxide anion radical, and lipid peroxyl radicals unearths many of the flavonoid health promoting functions, which are important for managing diseases associated with oxidative damage such as diabetes mellitus [23]. Flavonoids in human diet may reduce the risk of various cancers as well as prevent menopausal symptoms [24]. Therefore, the antioxidant effect and the antidiabetic activities of MP are suspected to be due to its flavonoid component as observed both in vitro and in vivo, respectively.

Alkaloids of plant origin such as Solanine from S. gilo fruit have been linked with the improvement in the symptoms of diabetes mellitus; also those of Momordica charantia have been reported to improve the diabetes condition $[25,26]$. Hence, it is also possible that the alkaloids present in MP may be responsible for the observed hypoglycaemic potential and associated effects on cholesterol levels in test rats.

Furthermore, increased glycogenesis, glycolysis, decreased glycogenolysis, and reduced carbohydrate breakdown as well as potential reduction in glucose absorption are further proposed as possible mechanisms of antidiabetes activity with MP.

Also, close correlations between cholesterol levels in blood and the diabetes have been previously reported [27, 28]. Elevated cholesterol (TC) and low-density lipoproteins (LDL-C) levels in the blood of diabetics are considered the primary cause of coronary heart disease (CHD) [2931]. The reduction of TC and LDL-C by drugs and diet could reduce CHD risk [22, 32]. The reduction of cholesterol levels observed in the present study coinciding with earlier reports unearths potential cardioprotective effects also of $M$. oppositifolius.

The findings with MP extract in this study confirm its folkloric uses in the management of diabetes, thus making Mallotus oppositifolius a probable plant for drug discoveries.

\section{Conclusion}

Bioactive components of the leaf extracts of M. oppositifolius may suggest multiple mechanisms of action in the control of blood and cholesterol levels.

Further studies will be needed to isolate and purify the bioactive compound(s) in the extract for bioassay-guided 
experiments in a view to pin-point its mechanisms of antidiabetic action. MP poses as a potential for ground-breaking diabetes study.

\section{Conflict of Interests}

The authors declare that there is no conflict of interests as per this work, the project was not funded by any organization, and appropriate acknowledgments have been given to those deserving.

\section{Acknowledgments}

The staff of the Bioresources Development and Conservation Programme (BDCP), a Botanical Research Center at Nsukka, the staff of the Animal House and those of the Department of Veterinary Physiology and Pharmacology, University of Nigeria, Nsukka, Enugu State, Nigeria, are gratefully acknowledged for their valuable contributions to the success of the study.

\section{References}

[1] M. K. Vinuthan, G. Kumara, M. Narayanaswamya, and T. Veena, "Lipid lowering effect of aqueous leaves extract of Murraya koenigii (curry leaf) on alloxan-induced male diabetic rats," Pharmacognosy Magazine, vol. 3, pp. 112-115, 2007.

[2] I. I. Ezeigbo, "Antidiabetic potential of methanolic leaf extracts of Icacina trichantha in alloxan-induced diabetic mice," International Journal of Diabetes in Developing Countries, vol. 30, no. 3, pp. 150-152, 2010.

[3] R. V. Jayakumar, "Herbal medicines for type-2 diabetes," International Journal of Diabetes in Developing Countries, vol. 30, no. 3, pp. 111-112, 2010.

[4] M. R. Taskinen, "Lipoprotein lipase in diabetes," Diabetes/ Metabolism Reviews, vol. 3, no. 2, pp. 551-570, 1987.

[5] A. Scoppola, F. R. Montecchi, G. Menzinger, and A. Lala, "Urinary mevalonate excretion rate in type 2 diabetes: role of metabolic control," Atherosclerosis, vol. 156, no. 2, pp. 357-361, 2001.

[6] K. Uchimura, A. Nagasaka, R. Hayashi et al., "Changes in superoxide dismutase activities and concentrations and myeloperoxidase activities in leukocytes from patients with diabetes mellitus," Journal of Diabetes and Its Complications, vol. 13, no. 5-6, pp. 264-270, 1999.

[7] N. H. Ugochukwu, N. E. Babady, M. Cobourne, and S. R. Gasset, "The effect of Gongronema latifolium extracts on serum lipid profile and oxidative stress in hepatocytes of diabetic rats," Journal of Biosciences, vol. 28, no. 1, pp. 1-5, 2003.

[8] F. A. Kabran, A. Maciuk, T. A. Okpekon et al., "Phytochemical and biological analysis of M. oppositifolius (Euphorbiaceae)," Planta Medica, vol. 78, no. 11, p. 1381, 2012.

[9] E. O. Farombi, O. O. Ogundipe, and J. O. Moody, "Antioxidant and anti-inflammatory activities of Mallotus oppositifolium in model systems," African Journal of Medicine and Medical Sciences, vol. 30, no. 3, pp. 213-215, 2001.

[10] M. M. Iwu, Handbook of African Medicinal Plants, CRC Press, Boca Raton, Fla, USA, 1993.

[11] M. U. Anthony and A. O. Adebimpe, "Hypoglycemic potential of the young leave methanolic extract of Mangifera indica in alloxan induced diabetic rat," Pakistan Journal of Nutrition, vol. 8, no. 3, pp. 239-241, 2009.

[12] I. I. Ezeigbo, "The antidiabetic potentials of the methanolic seed extract of Buchhlozia coriacea," Annals of Medical and Health Sciences Research, vol. 1, no. 2, pp. 159-163, 2011.

[13] N. Malviya, S. Jain, and S. Malviya, "Antidiabetic potential of medicinal plants," Acta Poloniae Pharmaceutica-Drug Research, vol. 67, no. 2, pp. 113-118, 2010.

[14] F. W. Sunderman Jr., A. Marzouk, S. M. Hopfer, S. M. Hopfer, O. Zaharia, and M. C. Reid, "Increased lipid peroxidation in tissues of nickel chloride-treated rats," Annals of Clinical and Laboratory Science, vol. 15, no. 3, pp. 229-236, 1985.

[15] C. C. Allain, L. S. Poon, and C. S. G. Chan, "Enzymatic determination of total serum cholesterol," Clinical Chemistry, vol. 20, no. 4, pp. 470-475, 1974.

[16] F. F. Benzie and J. J. Strain, "Ferric reducing/antioxidant power assay: direct measure of total antioxidant activity of biological fluids and modified version for simultaneous measurement of total antioxidant power and ascorbic acid concentration," Methods in Enzymology, vol. 299, pp. 15-27, 1998.

[17] L. L. Mensor, F. S. Menezes, G. G. Leitão et al., "Screening of Brazilian plant extracts for antioxidant activity by the use of DPPH free radical method," Phytotherapy Research, vol. 15, no. 2, pp. 127-130, 2001.

[18] G. H. Schmelzer, E. G. Achigan-Dako, and C. H. Bosch, Medicinal Plants of Tropical Africa, PROTA Foundation, Nairobi, Kenya, 2010.

[19] S. P. Wolff, Z. Y. Jiang, and J. V. Hunt, "Protein glycation and oxidative stress in diabetes mellitus and ageing," Free Radical Biology and Medicine, vol. 10, no. 5, pp. 339-352, 1991.

[20] R. N. Okigbo, C. L. Anuagasi, and J. E. Amadi, "Advances in selected medicinal and aromatic plants indigenous to Africa," Journal of Medicinal Plant Research, vol. 3, no. 2, pp. 86-95, 2009.

[21] E. Middleton Jr., C. Kandaswami, and T. C. Theoharides, “The effects of plant flavonoids on mammalian cells: implications for inflammation, heart disease, and cancer," Pharmacological Reviews, vol. 52, no. 4, pp. 673-751, 2000.

[22] D. E. Gutstein and V. Fuster, "Pathophysiology and clinical significance of atherosclerotic plaque rupture," Cardiovascular Research, vol. 41, no. 2, pp. 323-333, 1999.

[23] M. O. Sofidiya, O. A. Odukoya, O. B. Familoni, and S. I. Inya-Agha, "Free radical scavenging activity of some Nigerian medicinal plant extracts," Pakistan Journal of Biological Sciences, vol. 9, no. 8, pp. 1438-1441, 2006.

[24] P. Hodek, P. Trefil, and M. Stiborová, "Flavonoids-potent and versatile biologically active compounds interacting with cytochromes P450," Chemico-Biological Interactions, vol. 139, no. 1, pp. 1-21, 2002.

[25] M. B. Krawinkel and G. B. Keding, "Bitter gourd (Momordica charantia): a dietary approach to hyperglycemia," Nutrition Reviews, vol. 64, no. 7, pp. 331-337, 2006.

[26] J. K. Grover, S. Yadav, and V. Vats, "Medicinal plants of India with anti-diabetic potential," Journal of Ethnopharmacology, vol. 81, no. 1, pp. 81-100, 2002.

[27] K. Azad, J. M. Parkin, S. Court, M. F. Laker, and K. G. M. M. Alberti, "Circulating lipids and glycaemic control in insulin dependent diabetic children," Archives of Disease in Childhood, vol. 71, no. 2, pp. 108-113, 1994.

[28] V. A. Diwadkar, J. W. Anderson, S. R. Bridges, M. S. Gowri, and P. R. Oelgten, "Postprandial low-density lipoproteins in type 
2 diabetes are oxidized more extensively than fasting diabetes and control samples," Proceedings of the Society for Experimental Biology and Medicine, vol. 222, no. 2, pp. 178-184, 1999.

[29] B. Rodrigues and J. H. McNeil, "Cardiac function in spontaneously hypertensive diabetic rats," The American Journal of Physiology-Heart and Circulatory Physiology, vol. 251, no. 3, part 2, pp. H571-H580, 1986.

[30] J. J. Genest, J. R. McNamara, D. N. Salem, and E. J. Schaefer, "Prevalence of risk factors in men with premature coronary artery disease," The American Journal of Cardiology, vol. 67, no. 15, pp. 1185-1189, 1991.

[31] M. D. Sharma, J. A. Farmer, and A. Garber, "Type 2 diabetes and cardiovascular risk factors," Current Medical Research and Opinion, vol. 27, supplement 3, pp. 1-5, 2011.

[32] G. N. Levine, J. F. Keaney Jr., and J. A. Vita, "Cholesterol reduction in cardiovascular disease-clinical benefits and possible mechanisms," The New England Journal of Medicine, vol. 332, no. 8, pp. 512-521, 1995. 

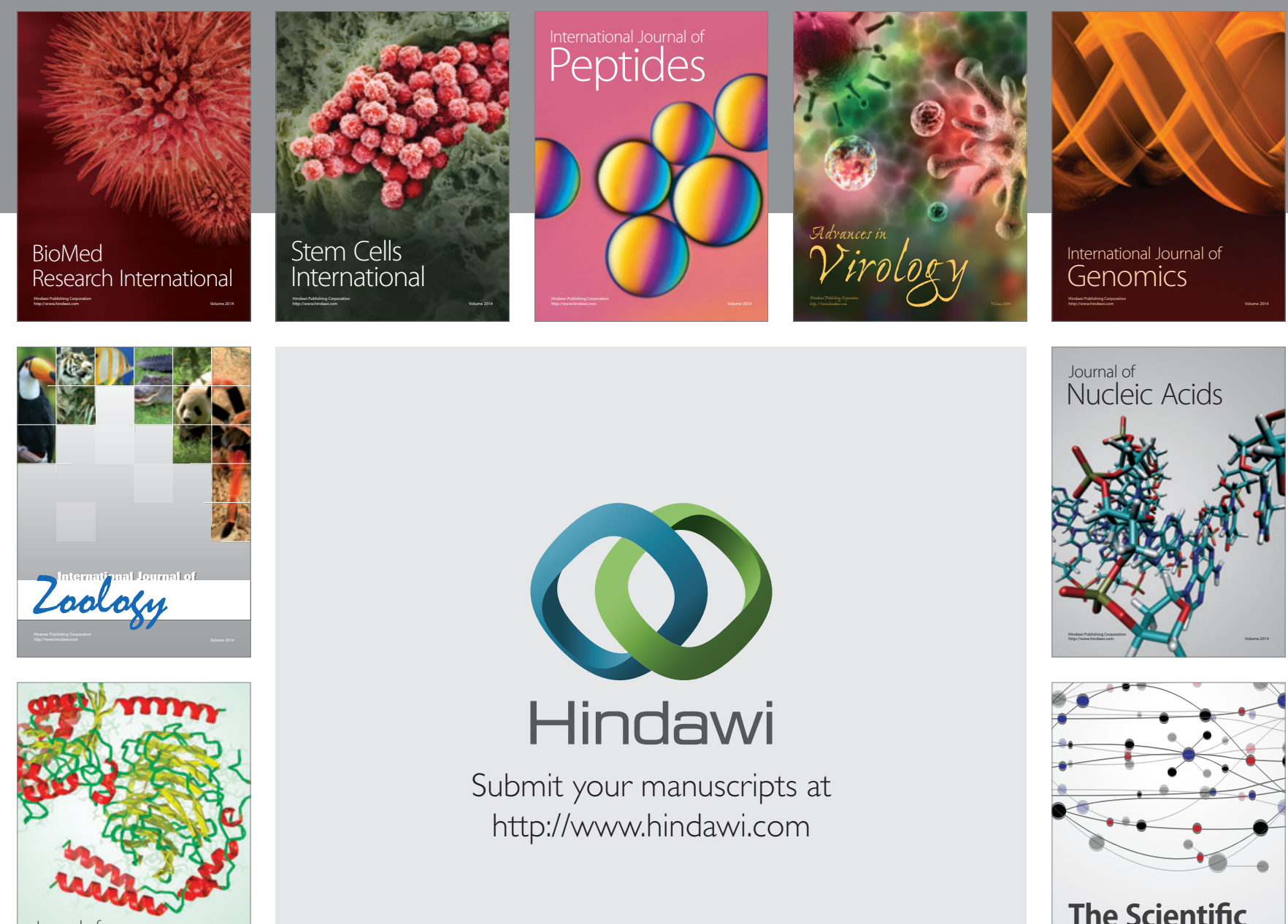

Submit your manuscripts at

http://www.hindawi.com

Journal of
Signal Transduction
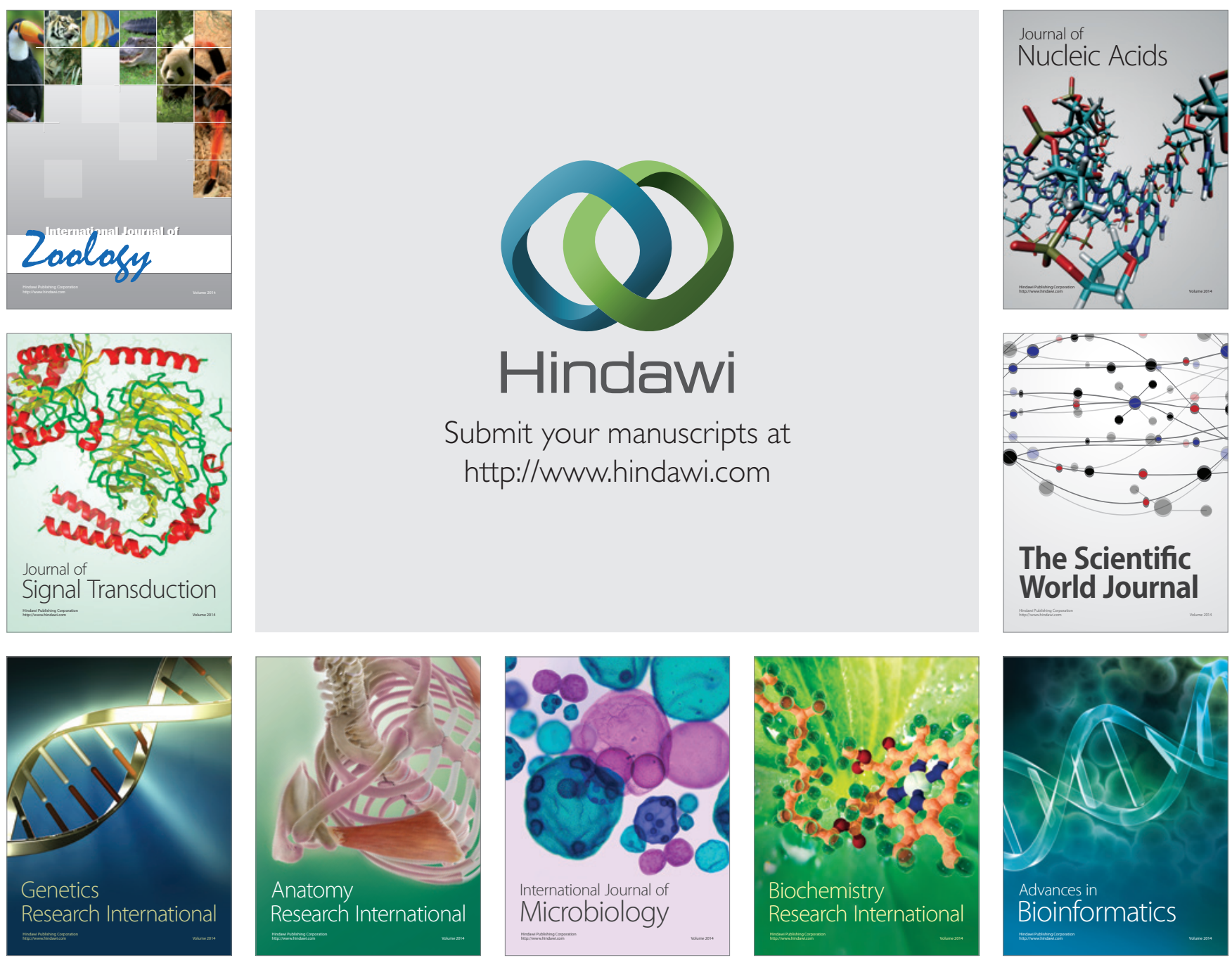

The Scientific World Journal
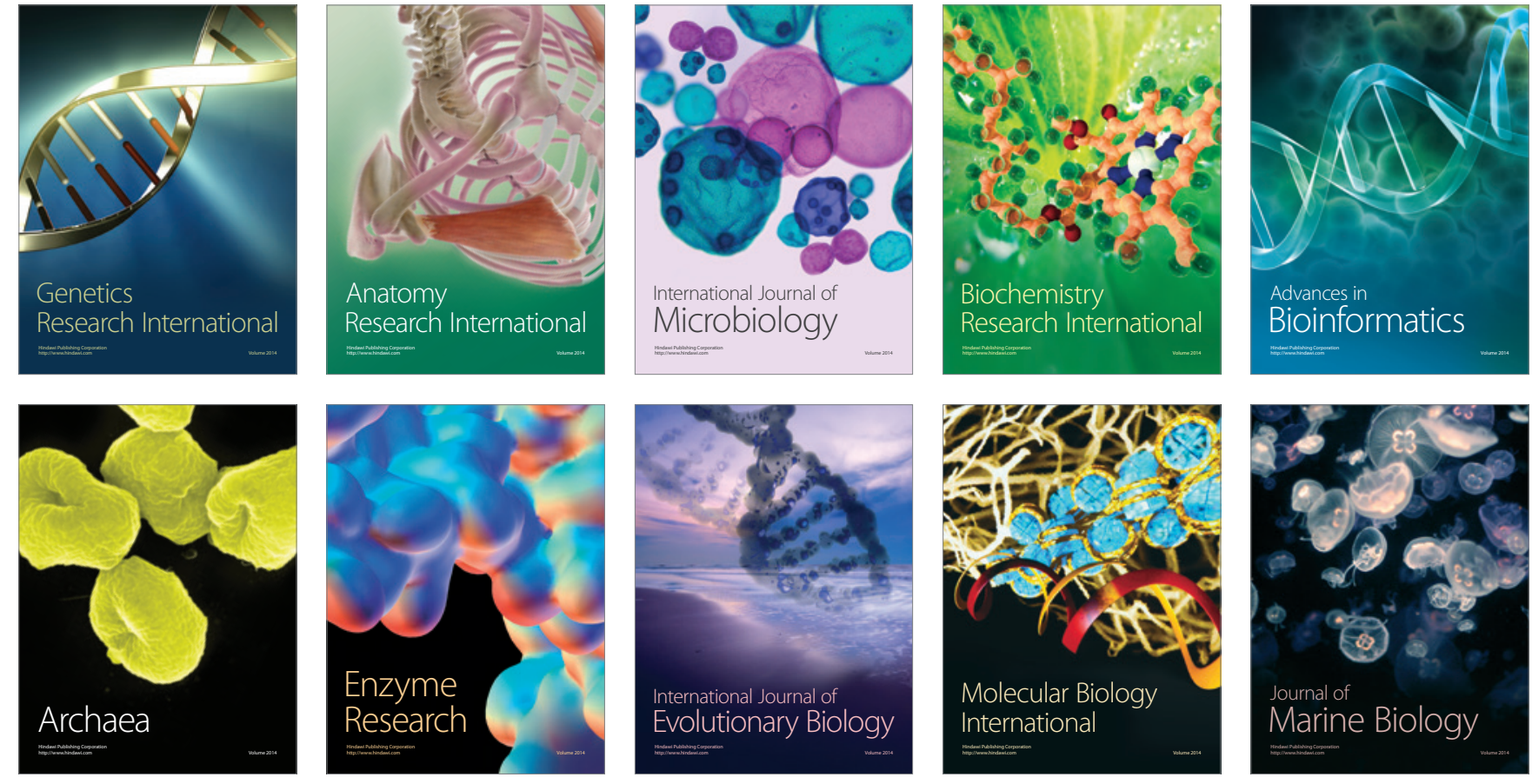